\title{
EFFECT OF WAGES ON MULTIPLE JOB HOLDING DECISIONS IN INDONESIA: EVIDENCE FROM THE INDONESIAN FAMILY LIFE SURVEY (IFLS) DATA OF 2007 AND 2014
}

\author{
Niken Dwi Wijayanti \\ Faculty of Economics and Business, Universitas Indonesia, Indonesia \\ (nikendwi.wijayanti86@gmail.com) \\ Vid Adrison \\ Faculty of Economics and Business, Universitas Indonesia, Indonesia \\ (vadrison@yahoo.com)
}

\begin{abstract}
Multiple job holding - i.e., a phenomenon in which workers have more than one job-has become a trend in developed countries and is beginning to occur in developing countries, such as Indonesia. Existing studies provide the evidence that wages are a significant and consistent criterion to determine multiple job decisions. Wage increases in the primary job will decrease the incentive to have a second job as the reservation wage increases. However, we do not find any study which links the current multiple job decision with the past multiple job status. In this study, we use data from the Indonesian Family Life Survey (IFLS) in 2007 and 2014 to investigate whether or not a wage increase in the primary job reduces the incentive to have asecond job in 2014, controlling for the multiple job status in 2007. Using logit and multinomial logit estimations, we find that the wage increase in the primary job decreases the probability of having a second job in 2014.
\end{abstract}

Keywords: multiple job holding, wages, employment, main job, second job

JEL Classification: D31, I31, J22, K31 


\section{INTRODUCTION}

\section{Background}

The phenomenon of workers who have more than one job is known as multiple job holding (Shishko \& Rostker, 1976). There are four main models that illustrate the motives that encourage workers to have multiple jobs (Casacuberta \& Gandelman, 2012; Martinez, Western, Haynes, Tomaszewski, \& Macarayan, 2014; Wu, Baimbridge, \& Zhu, 2009; Panos, Pouliakas, \& Zangelidis, 2014). The first is the hours constrained model, in which workers are unable to increase their working hours to adesired level due to the rigidity of the working hours in the primary job (i.e., the maximum provision for working hours set by the company). Therefore, workers decide to seek asecond job (Bell, Hart, \& Wright, 1997; Shishko \& Rostker, 1976; Smith Conway \& Kimmel, 1998).

The willingness of the worker to increase his/her working hours is closely related to the low or inadequate income from the main job. Workers will allocate their working time between two different jobs to meet their revenue objectives, assuming that they offer different financial and non financial benefits (Lundborg, 1995). This second model describes a worker doing multiple jobs based on the target income model.

The third model is the main job insecurity model. The changing times and the high level of competition make people consider having a second job. Workers whose primary jobs are vulnerable to, or at risk of termination will actively participate in multiple job holding to mitigate the possible effects of unemployment (Bell et al., 1997).

The fourth model that encourages the occurrence of multiple job holding is the heterogeneous job model. In this model, some workers may find an incentive to have more than one job because the different jobs are not perfect substitutes. This means that the wages paid and utility lost from forgoing leisure may not adequately reflect the benefits and costs of work (Smith Conway \& Kimmel, 1998).

In Indonesia, research into multiple job holding is still a bit in the academic realm. To the best of our knowledge, Martinez et al. (2014) were the first to analyze multiple job holding in Indonesia using the Indonesian Family Life Survey (IFLS) data from 1993, 2000, and 2007. They showed that the proportion of multiple job holders had increased over time, from $20 \%$ of the IFLS sample in 1993 to 23\% and 24\% in 2000 and 2007 respectively. This increase suggests that multiple job holding becomes an important issue for the Indonesian labor market. They conclude that the main motivation for multiple job holding is the constraints faced in the main job, both income constraints, and nonincome constraints. An increase in income in the main job reduces the probability of workers having multiple jobs. Although income is increasing over time, the number of multiple job holders are increasing. In our study, the empirical data indicates that more than $40 \%$ of people who had multiple jobs in 2007 still had multiple jobs in 2014, suggesting that it takes place permanently.

Some previous studies provide evidence that multiple job holding is either a permanent or temporary phenomenon of the labor market. A permanent phenomenon is a condition in which multiple job holding takes place continuously over time. Workers with more than one job, because of heterogeneous job motives tend to do so permanently. For example, university lecturers may also work on a consultation project, because both jobs are job-packaged, where the work is complementary (Bell et al., 1997; Kimmel \& Smith Conway, 2001). On the other hand, a multiple job holding is temporary 
if it takes place at a given time, where there are constrained hours, increased labor market uncertainty, and financial shocks. In this case, multiple job holding is deemed to be temporary to achieve a sub-optimal utility level derived from one's primary job, or as protection against the risks of unemployment (Casacuberta \& Gandelman, 2012; Kimmel \& Smith Conway, 2001; Panos et al., 2014; Wu et al., 2009). When faced with this, workers will look for opportunities to overcome these obstacles, one of which is by finding a new job. There is some limited empirical evidence suggesting that constraints in their main job play a role in the employee's decision to change the main job or do a side job (Altonji \& Paxson, 1988; Paxson \& Sicherman, 1996). Thus, if the worker has multiple jobs due to the response to constraints in the main job, it will take place temporarily. However, there are situations where workers who are constrained in their main job may decide to have side jobs related to their interests so that there is a possibility of permanence.

Research into multiple job holding highlights that wages are a significant and consistent criterion. Empirical evidence suggests that increased wages in the main job will increase the minimum wage that drives the individual to have a second job (reservation wage). Increased wages in the main job can also reduce the number of hours worked in the second job (Shishko \& Rostker, 1976). Wu et al. (2009) suggest that male workers who are not satisfied with their total earnings from their main job will be highly motivated to find second jobs, while higher-wage job opportunities will increase the supply of work-hours in the second job for both men and women. This indicates that the incentive to have multiple jobs is due to financial pressures and a desire to improve or maintain a standard of living. Martinez et al. (2014) also found that the tendency for multiple job holding decreased when individuals experienced an increase in income from their main job, demonstrating consistency with the target income model. However, the presence of high-income individuals who perform multiple job holding explains that this is not always due to financial constraints in the main job. In line with the findings, Panos et al. (2014) identify that for low-income groups, multiple job holding is more of a necessity than an option. As for stable income groups, multiple job holding can be used to acquire new skills and develop skills, explore alternative career paths and pursue the possibility of self-employment activities through self-employment.

Based on the above description, multiple job holding can provide several benefits for the worker. One of them is to provide an extra income which is very useful, especially for emergency purposes (Danzer, 2011). Multiple jobs can also provide additional satisfaction, especially when the second job is related to one's interests (Renna \& Oaxaca, 2006). They can also maintain the flexibility of working time (for example, women who have small children can do two part-time jobs, one job in the morning when the child is in school and the other in the afternoon when her husband comes home from work and can replace her in taking care of the child) (Averett, 2001). In addition to any financial constraints, recent evidence from industrialized countries suggests that multiple job holding can also be used to further develop any current skills and acquire new skills, which in turn can lead to better employment opportunities (Panos et al., 2014). This type of labor supply behavior can be part of a person's portfolio as a long-term strategy for future career development. Therefore, it is safe to conclude that financial and non financial factors can encourage a person to engage in multiple job holding. 
However, in some cases, multiple job holding is also potentially harmful to workers. Second jobs can reduce a person's productivity due to the shifting focus of the worker, due to the heavy workload, including the potential for conflict between the demands of the main job and the second job. Multiple job holding can also mean less time to find more productive job prospects. Furthermore, this type of labor supply behavior can have adverse consequences for one's health and family relationships if it means working more extended hours (Alam, Biswas, \& Hassan, 2009; ILO, 2004; Panos et al. 2014). Thus, although multiple job holding has the potential to provide more economic opportunities and strengthen the workforce, it also allows for increased employment vulnerability to socio-economic uncertainty.

Due to the losses that may result from multiple job holding, Dickey, Watson, and Zangelidis (2009) identified three main reasons why a person does not have multiple jobs. First, individuals are not interested in multiple job holding. Secondly, they want multiple jobs but cannot find a second job with interesting characteristics. Third, the individual wants multiple jobs but does not find a second job. There are two possible reasons why an individual cannot find a second job while another individual can. First, individuals may be less informed about the available job opportunities. Secondly, the individual applying for a second job may not meet the criteria desired by the company.

\section{Research Problem}

The relatively high number of workers with multiple jobs in Indonesia, either permanently or temporarily has become an interesting topic for research. The IFLS data indicate that $45 \%$ of workers who were holding multiple job sin 2007 continued to do so in 2014, indicating a permanent phenomenon (Table 1). Meanwhile, the other 55\% do so temporarily. Approximately 23\% of single job holders in 2007 switched to become multiple job holder sin 2014.

Employment decisions about multiple job holding, either permanently or temporarily, are closely related to wage or income issues in the main job. According to Shishko \& Rostker (1976), the labor supply becomes more elastic to wage changes if individuals decide to have multiple jobs due to the constrained hours in their main job, where the income they receive from their main job may be insufficient to meet their needs. Changes in wages in the main job will also alter the required reservation wage to make individuals interested in having multiple jobs. If their income from their main job increases, individuals with multiple jobs in the previous period have a lower tendency to have multiple jobs in the next period (i.e., their multiple job holding is temporary). However,

Table 1. Number of Single Job Holders and Multiple Job Holders in 2014 along with their Initial Status in the 2007 Survey

\begin{tabular}{ccccc}
\hline & \multicolumn{3}{c}{ Year 2014 } & \multirow{2}{*}{ Total } \\
\cline { 3 - 4 } & & Single Job Holder & Multiple Job Holder & \\
\hline \multirow{4}{*}{ Year 2007} & 8,441 & 2,490 & $\mathbf{1 0 , 9 3 1}$ \\
& \multirow{2}{*}{ Single Job Holder } & $(77 \%)$ & $(23 \%)$ & $\mathbf{( 1 0 0 \% )}$ \\
& & 2,009 & 1,654 & 3,663 \\
& \multirow{2}{*}{ Multiple Job Holder } & $(55 \%)$ & $(45 \%)$ & $(\mathbf{1 0 0 \% )}$ \\
\cline { 2 - 4 } & Total & $\mathbf{1 0 , 4 5 0}$ & $\mathbf{4 , 1 4 4}$ & $\mathbf{1 4 , 5 9 4}$ \\
\hline
\end{tabular}

Source: Author's computation using data from IFLS 2007 and 2014 
there are two possibilities that cause the tendency for multiple job holding to become fixed or even increased (despite an income increase from the main job). First, the increase in income is still unable to meet their needs. Second, the motive for having multiple jobs is not a financial motive.

\section{Research Objective}

Based on the above description, this research will use IFLS data from 2007 and 2014 to investigate whether or not an income increase in the primary job affects the multiple job decision in 2014, controlling for the multiple job holding status in 2007. Estimations are conducted using logit estimation. For the robustness check, we also perform a multinomial regression, to account for any possible changes in the job holding status between 2007 and 2014.

\section{Benefits of Research}

By analyzing the effect of a wage increase on individuals' decisions to have multiple jobs, we expect to identify the underlying motives for having multiple jobs. For individuals with low incomes, it is widely believed that multiple job holding is more of a necessity than an option. As for more financially stable individuals, multiple job holding can be used as an alternative path for developing and enriching their skills, exploring alternative career paths and pursuing the possibility of entrepreneurial activities through entrepreneurship. Whether or not such assumptions are true, become an empirical issue. We argue that the answer will be useful for developing a policy to reduce the negative consequences of multiple job holding.

\section{LITERATURE REVIEW}

\section{Conceptual Framework}

In this section, we present the conceptual framework developed by Smith Conway and
Kimmel (1998) to analyze the effect of wage increases on the multiple job decision. Their model views individuals as optimizing agents with the goal of maximizing utility, or the level of satisfaction from consuming goods, services, or leisure, who are confronted with budget and time constraints. The available time can be allocated either to time in the labor market or to work that generates income and satisfaction, as well as time at home or leisure resulting in satisfaction but not income.

Taking into account that the hours offered on different jobs may not be the same, the hours worked on the main job, $h_{l}$, working hours on the second jobs, $h_{2}$, and (time spent on) leisure, $L$, enter into utility functions separately. The total utility can be written as follows:

$$
\text { Utility }=U\left(C, h_{1}, h_{2}, L\right)
$$

where $C$ is a combination of consumer goods. The consumption value is usually confronted with budget constraints whose value is equal to the wage income and non-wage income of individuals. This can be represented as follows:

$$
C=w_{1} h_{1}+w_{2} h_{2}+Y
$$

where $w_{i}$ is the average wage received from one hour working at job $i$, so $w_{i} h_{i}$ is the wage income from work $i$, and $Y$ is the non-wage income. The wage income from work is confronted with time constraints, where the number of hours available for each worker is limited:

$$
T=h_{1}+h_{2}+L
$$

where $T$ is the time constraint (hours constraint) which shows the maximum number of hours in a day,which is 24 hours. Graphically, this can be described by the indifference curve and the budget constraint. The indifference curve is a curve that describes the combination of income and leisure that an individual can accept to maintain their utility to some degree. The budget 
constraint describes the combination of goods and services that workers can get from their income. Note that the slope of the budget constraint is the same as the income level.

Substituting the above constraints into the utility function for $C$ and $L$, will result in the following utility-maximizing problem:

$$
\begin{aligned}
& \max _{h_{1}, h_{2}} U\left(w_{1} h_{1}+w_{2} h_{2}+Y, h_{1}, h_{2}, T-\right. \\
& \left.h_{1}-h_{2}\right)
\end{aligned}
$$

There are two types of multiple job holdings, i.e., constrained and non-constrained. In a constrained multiple job holding, the quality of the second job is usually lower than the main job. Conversely, in the unconstrained multiple job holding, the quality of the second job is equal to or better than the main job. We can use the utility-maximizing problem as written in (4) to describe both types of multiple job holding.

\subsection{Constrained Multiple Job Holding}

Figure 1 illustrates the concept of the hours constrained model. This figure shows three levels of utility a worker can achieve, depending on the conditions of his/her job. In this figure, curve $I_{l}$ shows the highest level of utility a worker can achieve with an average (hourly) wage of $w_{1}$ if he/she can spend $h_{1}+h_{2}$ hours working at their main job. The $I_{3}$ curve shows the lowest utility level that the same worker can reach if the worker can only spend $h_{1}$ hours atwork on theirmain job. This is due to the stipulation of the number of working hours set by the company so that workers cannot work for $H=h_{1}+h_{2}$. The figure also shows that workers can still reach a higher utility level than $I_{3}$, which is denoted by curve $I_{2}$, if the worker is willing to do a second job even though the job offers lower average hourly wages. The decision to conduct multiple job holdings depends on whether the wage-offer in the second job exceeds the reservation wage. The reservation wage in the second job is shown by the lowest utility level $I_{3}$ which is the intersection of the primary employment wage and $h_{1}$ working hours. If the wage-offer exceeds the reservation wage, the worker will take a second job that results in a greater utility.

For comparison, Figure 2 below shows the type of worker who chooses not to have multiple jobs. This is because the wage earned in the primary job maximizes the worker's utility or because the wage-offer in the second job does not exceed the reservation wage.

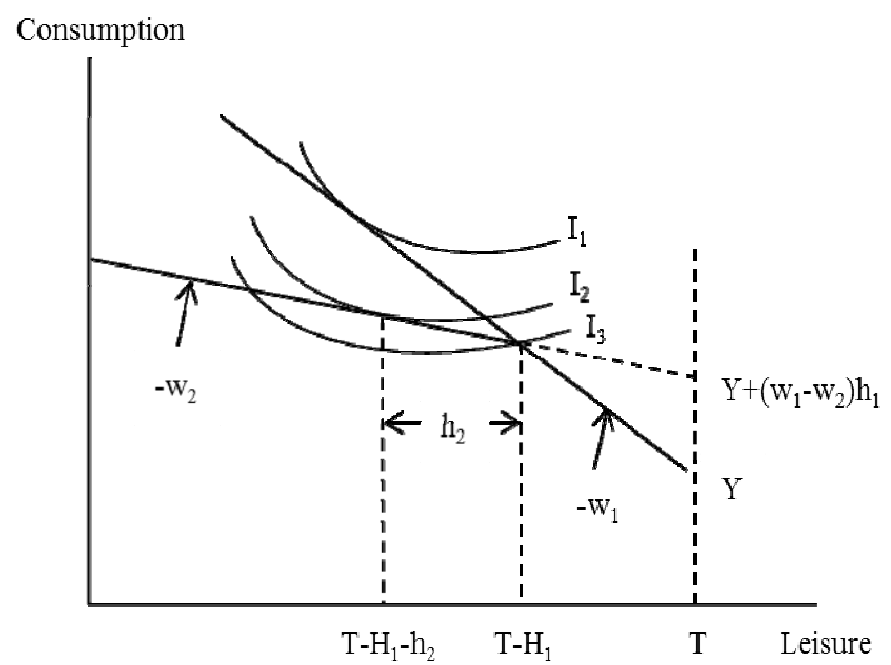

Figure 1 Utility Maximizing Decision of a Constrained Multiple Job Holding 
Source: Adopted from Averett (2001)

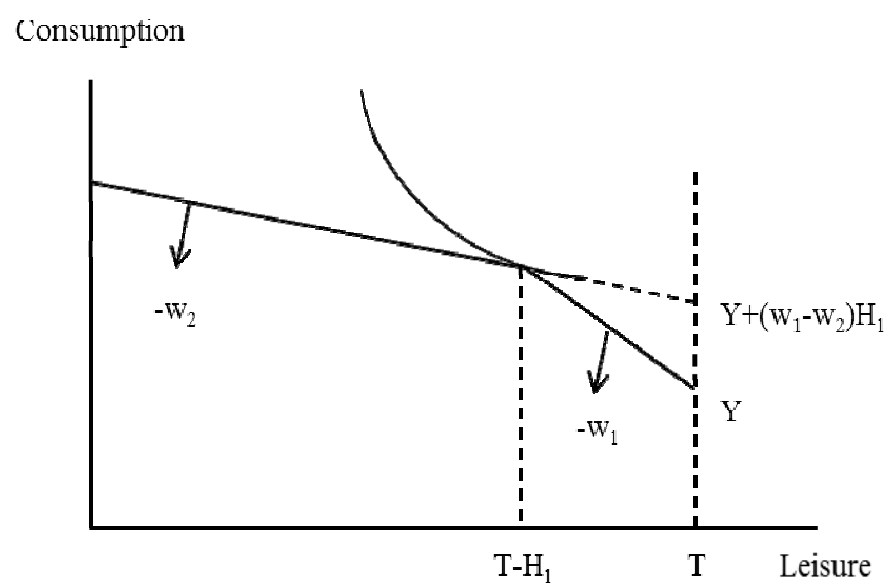

Figure 2 Utility Maximizing Decision of a Constrained Non Multiple Job Holding Source: Adopted from Smith Conway and Kimmel (1998)

In essence, if the worker is constrained by his/her working hours in their main job then $h_{l}$ is no longer a choice variable and the only way to increase the working hours is by having a second job. This is an example of a constrained multiple job holding in which workers will earn a lower income than a single job holder that has the same basic qualifications (and hence the same average wage of $w_{1}$ ) if he can work for $h_{1}+h_{2}$ hours. Based on the hours constrained models, the second job is inferior, in which this work provides a lower average (hourly) wage $w_{2}$ than the main job.

Substituting the time constraint ofthe main job $h_{l}=\overline{H_{1}}$ into the utility-maximizing problem of Equation (4), will produce the following equation:

$$
\begin{aligned}
& \max _{h_{2}} U\left(w_{1} \overline{H_{1}}+w_{2} h_{2}+Y, \overline{H_{1}}, h_{2}, T-\right. \\
& \left.\overline{H_{1}}-h_{2}\right)
\end{aligned}
$$

and generate the following optimization relationships:

$$
\left(U_{2}-U_{L}\right) / U_{c}=-w_{2}
$$

where $U_{2}$ is the partial derivative of the utility with respect to $h_{2}$. Then, $U_{2}-U_{L}$ is a marginal disutility of one hour working at a second job (the utility of a second job reduces the utility lost from forgone leisure). Equation (6) is a general condition between the reservation wage and the labor market wage. The individual will offer hours of work in the second job until the marginal disutility of an additional hour working in the second job, divided by the marginal utility of income, equals the (negative) wage paid in the second job $\left.\left(\left(U_{2}-U_{L}\right)\right) / U_{C}=-w_{2}\right)$.

The solution for the optimal hours worked in the second job will be as follows:

$$
h_{2}=h_{2}^{c}\left(w_{2}, Y+\left(w_{1}-w_{2}\right) \overline{H_{1}}, \overline{H_{1}}\right)
$$

where $Y+\left(w_{1}-w_{2}\right) h_{1}$ is the 'linearized' intercept of the new budget line segment. The letter $c$ written above signifies this function is a multiple job holding function for workers who are constrained by working hours in their main job.

\subsection{Non Constrained Multiple Job Holding}

Figure 3 below illustrates the concept of a nonhours constrained multiple job holding, where there is no hour constraint on the main job, so workers can work longer hours at that job if they wish. Taking a second job will be done if the 
wage paid for hat second job can yield the worker autility of at least $I_{l}$. In contrast to Figure 1 , this type of worker has an hourly average wage of $w_{2}$ offered by thesecond job, which should be higher than the average (hourly) wage in the main job $\left(w_{1}\right)$. Thus, the multiple job holder will earn more relative income compared to a single job holder. This may occur when the quality of the second job exceeds the quality of the main job (in this case, in its income-related dimensions).

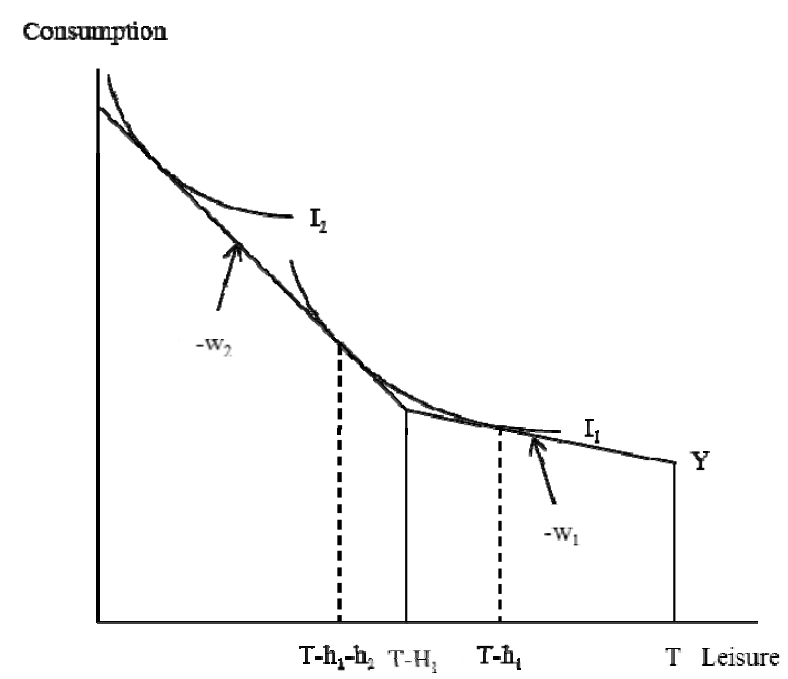

Figure 3 Utility Maximizing Decision of a NonConstrained Multiple Job Holding

Source: Adopted from Averett (2001)

The utility-maximization problem written in Equation (4), produces the optimization relationship as follows:

$$
\left(U_{i}-U_{L}\right) / U_{c}=-w_{i}, \text { untuk } \mathrm{i}=1,2
$$

Equation (8) explains that the individual will offer hours of work to each job until the marginal disutility of one hour worked on the job (the utility of the work is reduced by the utility lost from forgone leisure) divided by the marginal utility of income, equals the (negative) wages paid on the job. In fact, individuals who want to work with more work hours will always choose to work in a second job due to the higher wages. However, due to the possibility of the heterogenous characteristics of the work, there may be other reasons that encourage individuals to do both jobs. Thus, we can observe the work hour offer equation for both jobs as the following:

$$
h_{i}=h_{i}^{u}\left(w_{1}, w_{2}, Y\right), \text { for } \mathrm{i}=1,2
$$

Where $h_{i}^{u}$ denotes the unconstrained labor supply function. Comparative statics for such models, based on standard assumptions about the utility functions, show that $\partial h_{i} / \partial w_{j}<0$ for $i \neq j$, with an ambiguous sign when $i=j$. The assumption that leisure is a normal good shows $\partial h_{i} / \partial Y<0$.

\subsection{Multiple Job Holding Permanently or Temporarily}

The permanent or temporary phenomenon of multiple job holding can be explained in Figure 4 below. This image is a further development of the blend of Figures 1 and 2 of the constrained multiple job holding types.

In the figure above, curve $I$ shows the level of utility of a worker when multiple job holding occurs due to the working hours constraints in the primary job. This type of worker can only spend $h_{l}$ hours atwork at their primary job with an average (hourly) wage of $w_{1}$ so that his/her income is insufficient to meet their needs. To meet their needs, workers are willing to do a second job for up to $h_{2}$ hours even though the work offers a lower average (hourly) wage rate $w_{2}$. Curve $I^{\prime}$ shows the utility when the wage paid for the main job increase from $w_{1}$ to $w_{1}{ }^{\prime}$ $\left(\Delta 1 w_{l}\right)$, allowing workers to get out of multiple job holding if the wage increasecan meet their needs. However, since the increase in wages has not been able to meet his/herneeds, the worker must keep doing multiple jobs (i.e., permanent multi job holding). However, an increase in wages at their main job allows workers to spend less time doing second jobs $\left(h_{2}\right)$. The curve $I^{\prime \prime}$ 


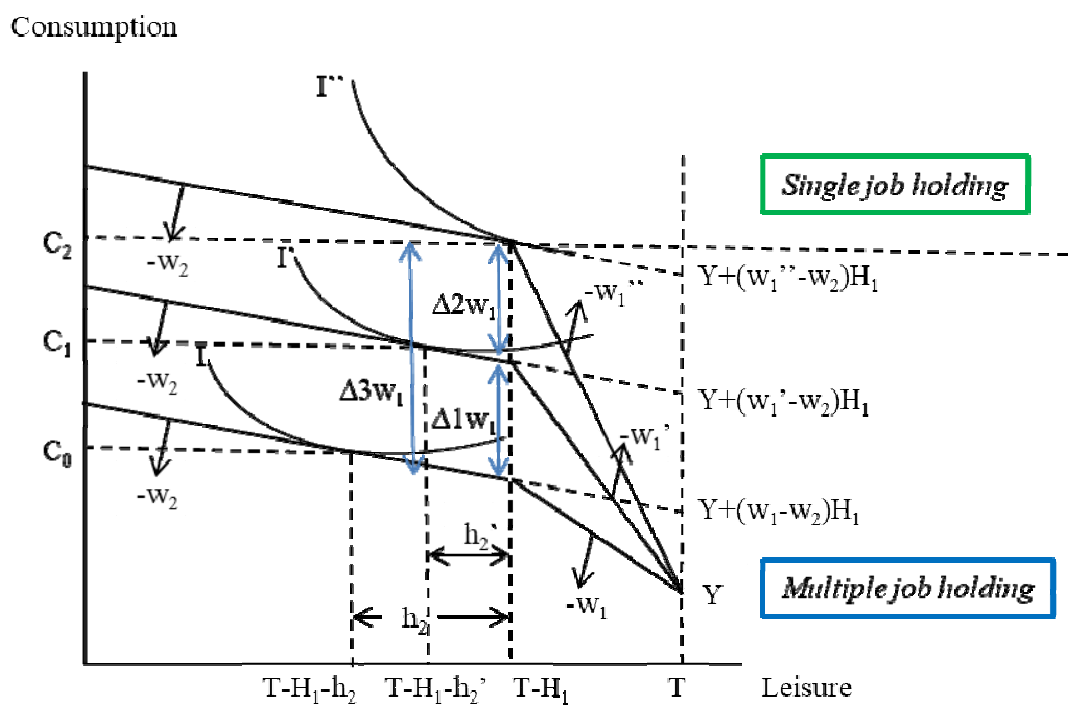

Figure 4 Utility Maximizing Decision of a Permanent and Temporary Multiple Job Holding Source: Author

shows the highest utility that can be achieved when the wage in the main job increase from $w_{l}{ }^{\prime}$ to $w_{1}^{\prime \prime}\left(\Delta 1 w_{2}\right)$. The $I^{\prime \prime}$ curve can also be achieved by the increase inthe main job's wage directly from $w_{1}$ to $w_{1}^{\prime \prime}\left(\Delta 1 w_{3}\right)$. This wage increase can meet the needs of workers, allowing workers to quit their multiple job holding. This condition enables workers to revert back to a single job (i.e., the multiple job holding is temporary).

\section{Previous Empirical Studies}

Based on the above theoretical explanation, the four motives underlying the workers having multiple jobs as described in the introductory section can be grouped as follows:

1. A constrained multiple job holding if the underlying motive is the hours constraint model, target income model, and main job insecurity model.

2. An unconstrained multiple job holding if the underlying motive is the heterogeneous jobs model.

In this regard, Friesen (2001) found that the constrained hours model caused by overtime pay regulations will increase the number of workers who perform multiple job holding. Friesen (2001) used the data from the Canadian Labor Survey in June 1997. Estimates were conducted by looking at how variations in the working hours and wages affect multiple job decisions. The empirical studies related to the target income model by Krishnan (1990) show the evidence of a relationship between employee income and the tendency for multiple job holding. Using the Survey of Income and Program Participation (SIPP, wave 2) data from February-April 1984, the research concludes that the tendency to have multiple jobs decreases as the income received from the main job increases. Nevertheless, the Robinson and Wadsworth (2007) study using Labor Force Survey data from 1998-2003 failed to find evidence that the introduction of minimum wages in the UK had a significant effect on employment decisions in multiple job holding. However, the main job's hours will increase for multiple job holders whose main jobs are not covered by minimum wages, and the second job's hours will drop when wages in the second job are below the minimum wage. 
Böheim and Taylor (2004) found that the existence of a permanent employment contract in the main job - as a proxy for job security - can reduce the tendency to seek second jobs. The study was conducted using the British Household Panel Survey (BHPS) data from 1990-1991. Danzer (2011) also showed empirical results for the main job insecurity model using Ukrainian Longitudinal Monitoring Survey (ULMS) data from 2003 and 2004. This study concluded that having a second economic activity can be used as a coping strategy for smoothing income and ensuring no work disruption during wage shocks in the main job. Furthermore, Renna and Oaxaca (2006) using the Current Population Survey (CPS) data from May 1991 found evidence of the heterogeneous model's motive. They found that some workers have personal preferences for job differentiation, where they derive different utility levels from their main job and their second job.

An empirical study regarding whether or not multiple job holding is permanent or temporary was conducted by Panos et al. (2014). In that research, Panos et al. (2014) used the British Household Panel Survey (BHPS) data from 1991-2005 and included a variable to reflect the initial status of multiple job holding in estimating the employment decisions about multiple job holding for the next few periods. They conclude that the coefficient of this variable is positive and significant, suggesting that multiple job holding takes place permanently. Furthermore, they argue that multiple job holding caused by financial shock is difficult to classify as a temporary phenomenon. This is because workers who do it permanently are lowpaid workers who are usually trapped in the "low-pay/no pay" cycle.

\section{Research Hypotheses}

Based on the theoretical model above, our research hypotheses are as follows:

1. The greater the increase is in income from the main job, this will lower the probability of an individual having multiple jobs in the next period

2. The greater the increase is in income from the main job, this will lower the probability of individuals permanently having multiple jobs, and increase the probability of individuals only having multiple jobs temporarily.

\section{METHOD, DATA, AND ANALYSIS}

\section{The Empirical Model}

Based on the theoretical model discussed in the previous section, the worker will have different supply functions of multiple job holding based on the underlying motives. In general, the number of working hours desired on a second job is distributed as follows (Equation 10).

$$
f\left(h_{2}\right)=\left[\begin{array}{c}
h_{2}^{c}\left(w_{2}, Y+\left(w_{1}-w_{2}\right) \overline{H_{1}}, \overline{H_{1}}\right) \text { if } h^{s}>h^{d}, \quad \text { or } f\left(h_{2} \mid h_{1}^{s}>h_{1}^{d}\right) \\
h_{2}^{u}\left(w_{1}, w_{2}, Y\right) \text { if } h^{s} \leq h^{d}, \quad \text { or } f\left(h_{2} \mid h_{1}^{s} \leq h_{1}^{d}\right)
\end{array}\right]
$$

where

$h^{s}$ : The number of work hours offered by the worker

$h^{d}$ : Number of hours requested by a company

$h_{1}^{s}$ : The number of work hours offered by the worker in the main job

$h_{1}^{d}$ : The number of work hours requested by the company in the main job 
Smith Conway and Kimmel (1998) use Equation (10) to estimate the behavior of multiple job holding using both a discrete and continuous dependent variable. They estimate the decision to have multiple jobs for all workers using a discrete dependent variable. The continuous variable was used to estimate the number of working hours in the second job for the multiple job holders only. From the working hours (in the second job) equation, it can be drawn that the probability is $h 2 \geq 0$. If $h 2>0$ then the worker will have multiple jobs, but if $h 2=0$ then the worker does not have a second job.

In this study, the focus is on the employee's decision to have multiple jobs, so that we use a discrete dependent variable. We use a logistic regression to determine whether or not a worker will have more than one job using the following general function:

$$
P(y=1 \mid x)=F\left(X_{i} \beta\right)
$$

with $F$ (.) being a logistic function, $X_{i}$ is the vector of factors affecting the decision of the worker to perform multiple job holding, and $\beta$ is the parameter vector.

Our sample consists of workers aged 15-65 years in the IFLS 2014 who were also available for IFLS 2007 and have a similar educational attainment in the two surveys. The dependent variable equals one if the workers have multiple jobs, and zero otherwise.

Our variable of interests consists of three variables. First, the change in monthly income from the main job between 2007 and 2014 (in the nominal term). Second, a dummy variable to reflect the multiple job holding status in 2007 (one if the worker had multiple jobs in 2007, zero otherwise). Third, the interaction of both variables (the income change from the main job multiplied by the initial multiple job status) on the primary job (nominal term, as a natural logarithm). The interaction variable reflects the effect of a change in income in the primary job between workers with a single job and those with multiple jobs.

To account for other contributing factors, we use the following set of control variables. First, the worker's characteristics which consists of the monthly income from the primary job (as a natural logarithm), a gender dummy (one for male worker, zero otherwise), age (in years), quadratic age, a dummy for primary education (one if the highest level of education is primary education, zero otherwise), a dummy for higher education (one ifthe worker has at least a college education, zero otherwise), and a marital status dummy (one if married, zero otherwise). Second, family characteristics which consist of the number of household members aged 15-64 who worked during the last twelve months (person), and the average of the other household member's monthly (nominal) income, and the hours spent at their primary job per month (in hours).

We use a location dummy (one if urban, zero otherwise), a dummy for the first job employment status (one if an employee, zero otherwise) and a job sector dummy (one if in agriculture, zero otherwise) as additional control variables. As Monk and Hodge (1995) argue, the labor market's structure is different from urban structures concerning its wage rates, transportation systems, and the trend with jobs is toward part-time. Generally, rural areas have narrow industrial bases, smaller numbers of entrepreneurs and the type of work is self-employed (Hodge, Dunn, Monk, \& Fitzgerald, 2002). Rural and urban differences in the labor market's structure are also reflected in the different job opportunities and job options available, as well as the dissemination of job-related information. In some cases, multiple job holding among agricultural households in rural areas arose as a result of the variability in agricultural incomes 
(Mather \& Scopilliti, 2004; Taylor \& Little, 1995).

To estimate the transition probability of multiple job status between 2007 and 2014, we conduct a Multinomial Logit (MNL) regression using the following general function:

$$
P\left(y_{t, i}=k \mid y_{t-1, i}=j\right)=F\left(X_{t, i} \beta\right)
$$

where $F$ (.) is a multinomial logistic function, $X_{t}$, ${ }_{i}$ is the vector of the factors affecting the decision of the worker to transition from state $j$ at $t-1$ to state $k$ at time $t$ (permanent or temporary multiple job holding), and $\beta$ is the parameter vector.

As there are two statuses (multiple job holder and single job holder) in each dataset, we have four job status categories as described in Table 2 .

The independent variables used in this model are the same as in the first model, except the initial status variables and the interaction variables (i.e., the income change from the main job multiplied by the initial multiple job status) are not included in the estimation model because they are self-reflected by the decision variables.

\section{Data}

This study uses IFLS data which is a national panel survey conducted by the Research and Development (RAND) Corporation. IFLS is a comprehensive survey of many aspects Indonesian domestic life, that collects data on income, consumption, health, education, employment, assets, migration, and others. Five waves of this survey have been conducted, i.e., in 1993, 1997, 2000, 2007, and 2014. In the first survey (1993) the samples covered 13 provinces, namely North Sumatra, West Sumatra, South Sumatra, Lampung, DKI Jakarta, West Java, Central Java, the Special Region of Yogyakarta, East Java, Bali, West Nusa Tenggara, South Kalimantan, and South Sulawesi. Although it only included these13 provinces in Indonesia, the IFLS results adequately illustrate $83 \%$ of the population of Indonesia (Strauss, Witoelar, \& Sikoki, 2016). In this study, we used the data from the two most recent IFLS, namely, the IFLS conducted in 2007 and 2014.

IFLS data can be used to analyze the probability of a worker doing multiple jobs, as the following questions (in the employment section of Book 3A) show:

1. Did you work/try to work/help to earn income for pay for at least 1 hour during the past week?

2. Did you have an additional job other than your main job?

3. Which category best describes your main job? Your second job? (Employment status) (self-employed, self-employed with unpaid family worker/temporary worker, selfemployed with permanent worker, government worker, private worker, casual worker in agriculture, casual worker not in agricul-

Table 2 Matrix Transition between $\mathrm{t}-1$ and $\mathrm{t}$

\begin{tabular}{cccc}
\hline & & \multicolumn{2}{c}{$\mathbf{t}$ (year 2014) } \\
\cline { 3 - 4 } & & $\begin{array}{c}\text { Single Job } \\
\text { Holder (S) }\end{array}$ & $\begin{array}{c}\text { Multiple Job } \\
\text { Holder (M) }\end{array}$ \\
\hline \multirow{2}{*}{ t-1 } & $\begin{array}{c}\text { Single Job } \\
\text { Holder }(\mathrm{S})\end{array}$ & $\mathrm{P}\left(\mathrm{y}_{\mathrm{t}}=\mathrm{S} \mid \mathrm{y}_{\mathrm{t}-1}=\mathrm{S}\right)$ & $\mathrm{P}\left(\mathrm{y}_{\mathrm{t}}=\mathrm{M} \mid \mathrm{y}_{\mathrm{t}-1}=\mathrm{S}\right)$ \\
(year 2007) & $\begin{array}{c}\text { Multiple Job } \\
\text { Holder }(\mathrm{M})\end{array}$ & $\mathrm{P}\left(\mathrm{y}_{\mathrm{t}}=\mathrm{S} \mid \mathrm{y}_{\mathrm{t}-1}=\mathrm{M}\right)$ & $\mathrm{P}\left(\mathrm{y}_{\mathrm{t}}=\mathrm{M} \mid \mathrm{y}_{\mathrm{t}-1}=\mathrm{M}\right)$ \\
\hline
\end{tabular}

Source: Author's classification 
ture, unpaid family worker)

4. What type of occupation do you have for your main job? For your second job?

5. What is the total number of hours worked during the past week at your main job? At your second job?

6. Approximately, including all benefits, how much do you earn from your main job? From your second job?

Information on the other socio-demographic characteristics of each respondent, such as the number of household members employed, the amount of income of other household members, educational background, and others is compiled with the employment module. From the combined dataset, we have 24,175 and 31,539 individuals from 2007 and 2014 respectively. In the process of selecting observation samples, as shown in Table 3, the working population in 2007 was 22,829 people, while in 2014 it was 29,004 people. The total number of workers aged 15-65 years old was 22,346 people in 2007 and 28,294 people in 2014. The next sample selection process is to select workers with a maximum number of 672 working hours per month (24 hours x 7 days $\times 4$ weeks). This results in a sample consisting of 22,260 people in 2007 and 28,094 people in 2014. From the 2007 data, the single job holders number17,214 people (77.33\%) and the multiple job holders 5,046 people (22.67\%). From the 2014 survey, the single job holders amounted to 21,350 people $(75.99 \%)$ and the multiple job holders totaled 6,744 people (24.01\%).

When estimating the logit and multinomial logit models, the main observations were limited to the same individuals in the two surveys from 2007 and 2014, and had similar educational attainments in both surveys. The final sample after cleaning the data amounted to 14,594 people, which comprised the single job and multiple job workers in 2014 along with their initial status, whether single or multiple job holders in the previous survey in 2007. This is summarized in Table 1.

\section{Descriptive Analysis Results}

The descriptive statistic of the individual characteristics of workers, the family characteristics of the individual workers, the environmental characteristics, and the characteristics of the labor market can be seen in Table 4 to Table 10 . Table 4 presents a descriptive statistic of the observations of the same working individuals from the two surveys in 2007 and 2014 and who havesimilar educational attainments in both surveys. Table 5 to Table 10 show theadditional descriptive statistics.

Table 3. Sample Selection of IFLS Data in 2007 and 2014

\begin{tabular}{|c|c|c|c|c|c|}
\hline & & \multicolumn{2}{|c|}{ Year 2007} & \multicolumn{2}{|c|}{ Year 2014} \\
\hline \multicolumn{2}{|c|}{ Total Observations of IFLS Data: } & \multicolumn{2}{|c|}{24,175} & \multicolumn{2}{|c|}{31,539} \\
\hline No. & Drop Observation if: & & & & \\
\hline 1. & Does Not Work & 1,346 & & 2,535 & \\
\hline 2. & Age $<15$ Years and $>65$ Years & 483 & & 710 & \\
\hline \multirow[t]{5}{*}{3.} & Working Hours> 672 Hours & 86 & & 200 & \\
\hline & Total Deleted Observations: & & 1,915 & & 3,445 \\
\hline & Total Sample Selected for Study: & & 22,260 & & 28,094 \\
\hline & Total Single Job Holder: & & 17,214 & & 21,350 \\
\hline & Total Multiple Job Holder: & & 5,046 & & 6,744 \\
\hline
\end{tabular}

Source: Author's computation using data from IFLS 2007 and 2014 
Table 4 Descriptive Statistics Characteristics of Individual Workers, Family Characteristics of Individuals Worker, Environmental Characteristics, and Characteristics of the Labor Market

\begin{tabular}{|c|c|c|c|c|}
\hline Variable & Mean & Std. Dev. & Min. & Max \\
\hline Multiple Job Holding & 0.284 & 0.451 & 0 & 1 \\
\hline Initial Status MJH & 0.251 & 0.434 & 0 & 1 \\
\hline$\Delta$ Income Main Job & $1,297,339$ & $1,710.748$ & $-11,923.8$ & $8,103,084$ \\
\hline Interaction & $201,414.6$ & $4,969.450$ & $-11,923.8$ & $2,980.958$ \\
\hline Ln(Income Main Job in 2007) & 13.258 & 1.023 & 2.303 & 19.807 \\
\hline Dummy Gender (1=Male) & 0.649 & 0.477 & 0 & 1 \\
\hline Age & 40.470 & 9.816 & 19 & 65 \\
\hline Age Square & $1,734.161$ & 842.829 & 361 & 4,225 \\
\hline Dummy Basic Education (1=Elementary School) & 0.353 & 0.478 & 0 & 1 \\
\hline Dummy High Education (1=University) & 0.139 & 0.346 & 0 & 1 \\
\hline Dummy Marital Status (1=Married) & 0.882 & 0.322 & 0 & 1 \\
\hline Number of Household Member Working & 3.604 & 2.013 & 0 & 17 \\
\hline Total Income other Household Member & $13,694,212$ & $83,823.798$ & 0 & $530,896.070$ \\
\hline Hours Work on Main Job (per month) & 164.719 & 91.002 & 0 & 640 \\
\hline Dummy Main Job Sector (1=Agriculture) & 0.241 & 0.427 & 0 & 1 \\
\hline Dummy Main Job Status (1=Paid Employee) & 0.522 & 0.500 & 0 & 1 \\
\hline Dummy Location (1=Urban) & 0.585 & 0.493 & 0 & 1 \\
\hline Ln(Income Increase Main Job) & 13.721 & 1.156 & 7.601 & 20.723 \\
\hline Ln(Increase Interaction) & 3.284 & 5.857 & 0 & 18.421 \\
\hline Ln(Income Decrease Main Job) & 12.818 & 1.256 & 8.517 & 19.806 \\
\hline Ln(Decrease Interaction) & 3.486 & 5.730 & 0 & 19.806 \\
\hline Observation & \multicolumn{4}{|c|}{14,594} \\
\hline
\end{tabular}

Source: Author's computation using data from IFLS 2007 and 2014

From Table 4, 28.4\% of the total workers in 2014 decided to conduct multiple job holding. Approximately $25.1 \%$ of our sample have multiple jobs in 2007. The average of the main job income per month between 2007 and 2014 is Rp1,297,339 with a maximum value of Rp8,103,084 and a minimum value of Rp11,923.8. This indicates that there are workers who experienced an increase in their income, as well as some who suffered a decrease, from their main work between the two survey periods. Out of 14,594 individuals there are 10,648 individuals who experienced an increase in their income, 2,587 people experienced a decreased income, and the remaining 1,359 people had a fixed income. The average increase in the main job income was $13.7 \%$, while the average decline for those who suffered a decreased income from the main job was $12.8 \%$. The average age of multiple job holders in 2014 is 40 years old, and the average working hours per month is 165 hours or 5-6 hours per day.

We can see that the overall number of male workers is almost twice of female workers (Table 5). The share of multiple job holders among the male workers is almost three time of the share of multiple job holders among the female workers (14.46\% vs. $5.55 \%)$. In contrast, female workers are more likely to have permanent single job rather than male workers (67.9\% vs. 52.4\%). From Table 6, it can be seen that workers with a secondary education is $50 \%$ of our sample. Workers who remain a single job holder is greater than $50 \%$ of samples for each education level. Based on education level, the share of permanent multiple job holders from samples with primary education is higher than 
two other groups (14\% vs. 9.2 and 9.9\%). From Table 7, we can see that the share of permanent multiple job holders in married workers is twice of single workers ( $12 \%$ vs. $6 \%$ ). On the contrary, the share of workers who remain as single job holder in the married workers is less than those of single workers.

Table 5. Sample Profiles of Single and Multiple Job Holdersin 2014 with Status in the 2007 Survey Period Based on Gender

\begin{tabular}{lccccc}
\hline Gender & $\begin{array}{c}\text { Number of Single- } \\
\text { Single Job Holder }\end{array}$ & $\begin{array}{c}\text { Number of Single- } \\
\text { Multiple Job } \\
\text { Holder }\end{array}$ & $\begin{array}{c}\text { Number of } \\
\text { Multiple-Single Job } \\
\text { Holder }\end{array}$ & $\begin{array}{c}\text { Number of } \\
\text { Multiple-Multiple } \\
\text { Job Holder }\end{array}$ & Total \\
\hline Male & 4,964 & 1,798 & 1,341 & 1,370 & $\mathbf{9 , 4 7 3}$ \\
& $(52.40 \%)$ & $(18.98 \%)$ & $(14.16 \%)$ & $(14.46 \%)$ & $\mathbf{( 1 0 0 \% )}$ \\
Female & 3,477 & 692 & 668 & 284 & $\mathbf{5 , 1 2 1}$ \\
& $(67.90 \%)$ & $(13.51 \%)$ & $(13.04 \%)$ & $(5.55 \%)$ & $\mathbf{( 1 0 0 \% )}$ \\
\hline \multirow{2}{*}{ Total } & $\mathbf{8 , 4 4 1}$ & $\mathbf{2 , 4 9 0}$ & $\mathbf{2 , 0 0 9}$ & $\mathbf{1 , 6 5 4}$ & $\mathbf{1 4 , 5 9 4}$ \\
& $\mathbf{( 5 7 . 8 4 \% )}$ & $\mathbf{( 1 7 . 0 6 \% )}$ & $\mathbf{( 1 3 . 7 7 \% )}$ & $\mathbf{( 1 1 . 3 3 \% )}$ & $\mathbf{( 1 0 0 \% )}$ \\
\hline
\end{tabular}

Source: Author's computation using data from IFLS 2007 and 2014

Table 6. Sample Profiles of Single and Multiple Job Holders in 2014 with Status in the 2007 Survey Period Based on the Highest Education ever/being Attended

\begin{tabular}{cccccc}
\hline Type of Education & $\begin{array}{c}\text { Number of } \\
\text { Single-Single } \\
\text { Job Holder }\end{array}$ & $\begin{array}{c}\text { Number of } \\
\text { Single-Multiple } \\
\text { Job Holder }\end{array}$ & $\begin{array}{c}\text { Number of } \\
\text { Multiple-Single } \\
\text { Job Holder }\end{array}$ & $\begin{array}{c}\text { Number of } \\
\text { Multiple-Multiple } \\
\text { Job Holder }\end{array}$ & Total \\
\hline Basic Education & 2,733 & 765 & 891 & 766 & $\mathbf{5 , 1 5 5}$ \\
& $(53.02 \%)$ & $(14.84 \%)$ & $(17.28 \%)$ & $(14.86 \%)$ & $\mathbf{( 1 0 0 \% )}$ \\
Secondary Education & 4,503 & 1,365 & 862 & 687 & $\mathbf{7 4 1 7}$ \\
& $(60.71 \%)$ & $(18.40 \%)$ & $(11.62 \%)$ & $(9.26 \%)$ & $\mathbf{( 1 0 0 \% )}$ \\
High Education & 1,205 & 360 & 256 & 201 & $\mathbf{2 , 0 2 2}$ \\
& $(59.59 \%)$ & $(17.80 \%)$ & $(12.66 \%)$ & $(9.94 \%)$ & $\mathbf{( 1 0 0 \% )}$ \\
\hline \multirow{2}{*}{ Total } & $\mathbf{8 , 4 4 1}$ & $\mathbf{2 , 4 9 0}$ & $\mathbf{2 , 0 0 9}$ & $\mathbf{1 , 6 5 4}$ & $\mathbf{1 4 , 5 9 4}$ \\
& $\mathbf{( 5 7 . 8 4 \% )}$ & $\mathbf{( 1 7 . 0 6 \% )}$ & $\mathbf{( 1 3 . 7 7 \% )}$ & $\mathbf{( 1 1 . 3 3 \% )}$ & $\mathbf{( 1 0 0 \% )}$ \\
\hline
\end{tabular}

Source: Author's computation using data from IFLS 2007 and 2014

Table 7. Sample Profiles of Single and Multiple Job Holders in 2014 with Status in the 2007 Survey Based on Marital Status

\begin{tabular}{lccccc}
\hline Marital Status & $\begin{array}{c}\text { Number of } \\
\text { Single-Single } \\
\text { Job Holder }\end{array}$ & $\begin{array}{c}\text { Number of } \\
\text { Single-Multiple } \\
\text { Job Holder }\end{array}$ & $\begin{array}{c}\text { Number of } \\
\text { Multiple-Single } \\
\text { Job Holder }\end{array}$ & $\begin{array}{c}\text { Number of } \\
\text { Multiple-Multiple } \\
\text { Job Holder }\end{array}$ & Total \\
\hline Married & 7,328 & 2,207 & 1,795 & 1,546 & $\mathbf{1 2 , 8 7 6}$ \\
\multirow{2}{*}{ Not Married } & $(56.91 \%)$ & $(17.14 \%)$ & $(13.94 \%)$ & $(12.01 \%)$ & $\mathbf{( 1 0 0 \% )}$ \\
& 1,113 & 283 & 214 & 108 & $\mathbf{1 , 7 1 8}$ \\
& $(64.78 \%)$ & $(16.47 \%)$ & $(12.46 \%)$ & $(6.29 \%)$ & $\mathbf{( 1 0 0 \% )}$ \\
\hline \multirow{2}{*}{ Total } & $\mathbf{8 , 4 4 1}$ & $\mathbf{2 , 4 9 0}$ & $\mathbf{2 , 0 0 9}$ & $\mathbf{1 , 6 5 4}$ & $\mathbf{1 4 , 5 9 5}$ \\
& $\mathbf{( 5 7 . 8 3 \% )}$ & $\mathbf{( 1 7 . 0 6 \% )}$ & $\mathbf{( 1 3 . 7 6 \% )}$ & $\mathbf{( 1 1 . 3 3 \% )}$ & $\mathbf{( 1 0 0 \% )}$ \\
\hline
\end{tabular}

Source: Author's computation using data from IFLS 2007 and 2014 
From Table 8, it can be seen that selfemployed workers have a higher share of having a permanent multiple job compare paid workers and unpaid family workers ( $14 \%$ vs. $9 \%$ and $7 \%$ respectively). The same pattern can also be seen for those who switched from single job holders to multiple job holders (19\% vs. $15 \%$ and $12 \%$ ). The share of paid workers and unpaid family workers who remain a single job holder is higher than self-employed workers. From Table 9, the share of permanent multiple job holders in agriculture is almost twice those in other sector (17\% vs. 9\%). The share of permanent multiple job holders in rural is $16.7 \%$, which is almost the same to the share of permanent job holders in agriculture sector (Table 10).

Table 8 Sample Profiles of Single and Multiple Job Holder Workers in 2014 and their Status in the 2007 Survey Period Based on Main Employment Status

\begin{tabular}{cccccc}
\hline Main Job Status & $\begin{array}{c}\text { Number of } \\
\text { Single-Single } \\
\text { Job Holder }\end{array}$ & $\begin{array}{c}\text { Number of } \\
\text { Single-Multiple } \\
\text { Job Holder }\end{array}$ & $\begin{array}{c}\text { Number of } \\
\text { Multiple-Single } \\
\text { Job Holder }\end{array}$ & $\begin{array}{c}\text { Number of } \\
\text { Multiple-Multiple } \\
\text { Job Holder }\end{array}$ & Total \\
\hline Self Employed & 2,966 & 1,165 & 936 & 891 & 5,958 \\
& $(49.78 \%)$ & $(19.55 \%)$ & $(15.71 \%)$ & $(14.95 \%)$ & $(\mathbf{1 0 0 \% )}$ \\
Paid Worker & 4,825 & 1,194 & 913 & 687 & 7,619 \\
& $(63.33 \%)$ & $(15.67 \%)$ & $(11.98 \%)$ & $(9.02 \%)$ & $\mathbf{( 1 0 0 \% )}$ \\
Unpaid Family & 650 & 131 & 160 & 76 & $\mathbf{1 , 0 1 7}$ \\
Worker & $(63.91 \%)$ & $(12.88 \%)$ & $(15.73 \%)$ & $(7.47 \%)$ & $(\mathbf{1 0 0 \% )}$ \\
\hline \multirow{2}{*}{ Total } & $\mathbf{8 , 4 4 1}$ & $\mathbf{2 , 4 9 0}$ & $\mathbf{2 , 0 0 9}$ & $\mathbf{1 , 6 5 4}$ & $\mathbf{1 4 , 5 9 4}$ \\
& $\mathbf{( 5 7 . 8 4 \% )}$ & $\mathbf{( 1 7 . 0 6 \% )}$ & $\mathbf{( 1 3 . 7 7 \% )}$ & $\mathbf{( 1 1 . 3 3 \% )}$ & $\mathbf{( 1 0 0 \% )}$ \\
\hline
\end{tabular}

Source: Author's computation using data from IFLS 2007 and 2014

Table 9 Sample Profiles of Single and Multiple Job Holder Workers in 2014 and their Status in the 2007 Survey Period Based on Main Job Sector

\begin{tabular}{cccccc}
\hline $\begin{array}{c}\text { Main Job } \\
\text { Sector }\end{array}$ & $\begin{array}{c}\text { Number of } \\
\text { Single-Single } \\
\text { Job Holder }\end{array}$ & $\begin{array}{c}\text { Number of } \\
\text { Single-Multiple } \\
\text { Job Holder }\end{array}$ & $\begin{array}{c}\text { Number of } \\
\text { Multiple-Single } \\
\text { Job Holder }\end{array}$ & $\begin{array}{c}\text { Number of } \\
\text { Multiple-Multiple } \\
\text { Job Holder }\end{array}$ & Total \\
\hline Agriculture Sector & 1,602 & 673 & 624 & 611 & 3,510 \\
& $(45.64 \%)$ & $(19.17 \%)$ & $(17.78 \%)$ & $(17.41 \%)$ & $(\mathbf{1 0 0 \% )}$ \\
Non Agriculture & 6,839 & 1,817 & 1,385 & 1,043 & $\mathbf{1 1 , 0 8 4}$ \\
Sector & $(61.70 \%)$ & $(16.39 \%)$ & $(12.50 \%)$ & $(9.41 \%)$ & $\mathbf{( 1 0 0 \% )}$ \\
\hline \multirow{2}{*}{ Total } & $\mathbf{8 , 4 4 1}$ & $\mathbf{2 , 4 9 0}$ & $\mathbf{2 , 0 0 9}$ & $\mathbf{1 , 6 5 4}$ & $\mathbf{1 4 , 5 9 4}$ \\
& $(\mathbf{5 7 . 8 4 \% )}$ & $\mathbf{( 1 7 . 0 6 \% )}$ & $\mathbf{( 1 3 . 7 7 \% )}$ & $\mathbf{( 1 1 . 3 3 \% )}$ & $\mathbf{( 1 0 0 \% )}$ \\
\hline
\end{tabular}

Source: Author's computation using data from IFLS 2007 and 2014

Table 10. Sample Profiles of Single and Multiple Job Holder Workers in 2014 and their Status in the 2007 Survey Period Based on Residence

\begin{tabular}{cccccc}
\hline Residence & $\begin{array}{c}\text { Number of } \\
\text { Single-Single } \\
\text { Job Holder }\end{array}$ & $\begin{array}{c}\text { Number of } \\
\text { Single-Multiple } \\
\text { Job Holder }\end{array}$ & $\begin{array}{c}\text { Number of } \\
\text { Multiple-Single } \\
\text { Job Holder }\end{array}$ & $\begin{array}{c}\text { Number of } \\
\text { Multiple-Multiple } \\
\text { Job Holder }\end{array}$ & Total \\
\hline Urban & 5,543 & 1,424 & 925 & 642 & $\mathbf{8 , 5 3 4}$ \\
& $(64.95 \%)$ & $(16.69 \%)$ & $(10.84 \%)$ & $(7.52 \%)$ & $\mathbf{( 1 0 0 \% )}$ \\
\multirow{2}{*}{ Rural } & 2,898 & 1,066 & 1,084 & 1,012 & $\mathbf{6 , 0 6 0}$ \\
& $(47.82 \%)$ & $(17.59 \%)$ & $(17.89 \%)$ & $(16.70 \%)$ & $\mathbf{( 1 0 0 \% )}$ \\
\hline \multirow{2}{*}{ Total } & $\mathbf{8 , 4 4 1}$ & $\mathbf{2 , 4 9 0}$ & $\mathbf{2 , 0 0 9}$ & $\mathbf{1 , 6 5 4}$ & $\mathbf{1 4 , 5 9 4}$ \\
& $\mathbf{( 5 7 . 8 4 \% )}$ & $\mathbf{( 1 7 . 0 6 \% )}$ & $\mathbf{( 1 3 . 7 7 \% )}$ & $\mathbf{( 1 1 . 3 3 \% )}$ & $\mathbf{( 1 0 0 \% )}$ \\
\hline
\end{tabular}

Source: Author's computation using data from IFLS 2007 and 2014 


\section{Estimated Results}

4.1 Logit Estimation Results of Multiple Job Holding Decision
The estimation results of the wage effect on employees' decisions to perform multiple job holding based on their initial status of $\mathrm{MJH}$ for workers aged 15-65 years using a logit regression can be seen in Table 11 below.

Table 11. Logit Estimation Results of Multiple Job Holding Decision

\begin{tabular}{|c|c|c|c|c|c|c|}
\hline \multirow[b]{3}{*}{ Variabel } & \multicolumn{6}{|c|}{ Model Logit (1=Multiple Job Holding) } \\
\hline & \multicolumn{3}{|c|}{ Model 1} & \multicolumn{3}{|c|}{ Model 2} \\
\hline & $\begin{array}{c}\text { Full } \\
\text { Sample }\end{array}$ & $\begin{array}{c}\text { Sample with } \\
\text { Increased } \\
\text { Income } \\
\end{array}$ & $\begin{array}{c}\text { Sample with } \\
\text { Decreased } \\
\text { Income } \\
\end{array}$ & $\begin{array}{c}\text { Full } \\
\text { Sample }\end{array}$ & $\begin{array}{c}\text { Sample with } \\
\text { Increased } \\
\text { Income } \\
\end{array}$ & $\begin{array}{c}\text { Sample with } \\
\text { Decreased } \\
\text { Income } \\
\end{array}$ \\
\hline$\Delta$ Income Main Job & $\begin{array}{c}-0.00044 \\
(0.000)\end{array}$ & & & & & \\
\hline Initial MJH Status & $\begin{array}{l}0.12311 \\
(0.019)^{* * *}\end{array}$ & $\begin{array}{c}0.11248 \\
(0.082)\end{array}$ & $\begin{array}{l}-0.41065 \\
(0.255)^{*}\end{array}$ & $\begin{array}{r}0.12469 \\
(0.019)^{* * *}\end{array}$ & $\begin{array}{r}0.27897 \\
(0.070)^{* * *}\end{array}$ & $\begin{array}{l}-1.58693 \\
(0.949)^{*}\end{array}$ \\
\hline Interaction & $\begin{array}{c}0.00016 \\
(0.000)\end{array}$ & & & $\begin{array}{r}0.00017 \\
(0.000)\end{array}$ & & \\
\hline $\begin{array}{l}\text { Ln(Income Increase } \\
\text { from the Main Job) }\end{array}$ & & $\begin{array}{c}-0.02119 \\
(0.007)^{* * *}\end{array}$ & & & & \\
\hline $\begin{array}{l}\text { Ln(Income Increase) x } \\
\text { Initial MJH Status }\end{array}$ & & $\begin{array}{c}0.00138 \\
(0.007)\end{array}$ & & & $\begin{array}{c}-0.01301 \\
(0.004)^{* * *}\end{array}$ & \\
\hline $\begin{array}{l}\text { Ln(Income Decrease } \\
\text { from the Main Job) }\end{array}$ & & & $\begin{array}{c}-0.01546 \\
(0.015)\end{array}$ & & & \\
\hline Ln(Income Decrease) $x$ & & & 0.04391 & & & 0.17673 \\
\hline Initial MJH Status & & & $(0.020)^{* *}$ & & & $(0.074)^{* *}$ \\
\hline Ln(Income from the & -0.01382 & -0.00741 & -0.02385 & -0.01404 & -0.01015 & -0.16403 \\
\hline Main Job in 2007) & $(0.004)^{* * *}$ & $(0.004)^{*}$ & $(0.017)$ & $(0.004)^{* * *}$ & $(0.004)^{* *}$ & $(0.051)^{* * *}$ \\
\hline $\begin{array}{l}\text { Dummy Gender } \\
\text { (1=Male) }\end{array}$ & $\begin{array}{c}0.11823 \\
(0.018)^{* * *}\end{array}$ & $\begin{array}{c}0.123 \\
(0.026)^{* * *}\end{array}$ & $\begin{array}{c}0.19906 \\
(0.029)^{* * *}\end{array}$ & $\begin{array}{r}0.11820 \\
(0.018)^{* * *}\end{array}$ & $\begin{array}{r}0.09085 \\
(0.022)^{* * *}\end{array}$ & $\begin{array}{r}0.89563 \\
(0.105)^{* * *}\end{array}$ \\
\hline Age & $\begin{array}{c}0.00100 \\
(0.003)^{* * *}\end{array}$ & $\begin{array}{l}0.00596 \\
(0.004)^{*}\end{array}$ & $\begin{array}{c}0.02910 \\
(0.010)^{* * *}\end{array}$ & $\begin{array}{r}0.00997 \\
(0.003)^{* * *}\end{array}$ & $\begin{array}{l}0.00446 \\
(0.003)\end{array}$ & $\begin{array}{c}0.13101 \\
(0.038)^{* * *}\end{array}$ \\
\hline Age Square & $\begin{array}{c}-0.00013 \\
(0.000)^{* * *}\end{array}$ & $\begin{array}{l}-0.00008 \\
(0.000)^{*}\end{array}$ & $\begin{array}{c}-0.00037 \\
(0.000)^{* * *}\end{array}$ & $\begin{array}{r}-0.00013 \\
(0.000)^{* * *}\end{array}$ & $\begin{array}{l}-0.00006 \\
(0.000)^{*}\end{array}$ & $\begin{array}{c}-0.00166 \\
(0.000)^{* * *}\end{array}$ \\
\hline $\begin{array}{l}\text { Dummy Basic Education } \\
\text { (1=Elementary) }\end{array}$ & $\begin{array}{l}-0.01882 \\
(0.008)^{* *}\end{array}$ & $\begin{array}{l}-0.02572 \\
(0.011)^{* *}\end{array}$ & $\begin{array}{c}-0.03322 \\
(0.023)\end{array}$ & $\begin{array}{r}-0.01885 \\
(0.008)^{* *}\end{array}$ & $\begin{array}{l}-0.01786 \\
(0.008)^{* *}\end{array}$ & $\begin{array}{c}-0.14870 \\
(0.100)\end{array}$ \\
\hline $\begin{array}{l}\text { Dummy High Education } \\
\text { (1=University) }\end{array}$ & $\begin{array}{c}0.02688 \\
(0.010)^{* * *}\end{array}$ & $\begin{array}{c}0.04520 \\
(0.014)^{* * *}\end{array}$ & $\begin{array}{l}0.00771 \\
(0.036)\end{array}$ & $\begin{array}{r}0.02579 \\
(0.010)^{* * *}\end{array}$ & $\begin{array}{r}0.02909 \\
(0.010)^{* * *}\end{array}$ & $\begin{array}{c}-0.04100 \\
(0.162)\end{array}$ \\
\hline $\begin{array}{l}\text { Dummy Marital Status } \\
\qquad(1=\text { Married })\end{array}$ & $\begin{array}{c}0.01056 \\
(0.010)\end{array}$ & $\begin{array}{l}0.01064 \\
(0.012)\end{array}$ & $\begin{array}{l}0.01759 \\
(0.031)\end{array}$ & $\begin{array}{r}0.01042 \\
(0.010)\end{array}$ & $\begin{array}{l}0.00684 \\
(0.009)\end{array}$ & $\begin{array}{l}0.08067 \\
(0.145)\end{array}$ \\
\hline $\begin{array}{l}\text { Number of Household } \\
\text { Members Working }\end{array}$ & $\begin{array}{l}0.00036 \\
(0.002)\end{array}$ & $\begin{array}{l}0.00101 \\
(0.002)\end{array}$ & $\begin{array}{l}0.00136 \\
(0.005)\end{array}$ & $\begin{array}{l}0.00037 \\
(0.002)\end{array}$ & $\begin{array}{l}0.00084 \\
(0.001)\end{array}$ & $\begin{array}{l}0.00622 \\
(0.024)\end{array}$ \\
\hline $\begin{array}{l}\text { Total Income Other } \\
\text { Household Members }\end{array}$ & $\begin{array}{c}-0.00004 \\
(0.000)\end{array}$ & $\begin{array}{c}-0.00003 \\
(0.000)\end{array}$ & $\begin{array}{l}-0.00015 \\
(0.000)\end{array}$ & $\begin{array}{r}-0.00004 \\
(0.000)\end{array}$ & $\begin{array}{r}-0.00002 \\
(0.000)\end{array}$ & $\begin{array}{r}-0.00019 \\
(0.000)\end{array}$ \\
\hline $\begin{array}{l}\text { Hours Worked in } \\
\text { the Main Job (month) }\end{array}$ & $\begin{array}{c}-0.00042 \\
(0.000)^{* * *}\end{array}$ & $\begin{array}{c}-0.00044 \\
(0.000)^{* * *}\end{array}$ & $\begin{array}{c}-0.00039 \\
(0.000)^{* * *}\end{array}$ & $\begin{array}{r}-0.00043 \\
(0.000)^{* * *}\end{array}$ & $\begin{array}{r}-0.00035 \\
(0.000)^{* * *}\end{array}$ & $\begin{array}{c}-0.00171 \\
(0.000)^{* * *}\end{array}$ \\
\hline Dummy Main Job & 0.04266 & 0.04087 & 0.07170 & 0.04290 & 0.03126 & 0.31279 \\
\hline
\end{tabular}




\begin{tabular}{|c|c|c|c|c|c|c|}
\hline \multirow[b]{3}{*}{ Variabel } & \multicolumn{6}{|c|}{ Model Logit (1=Multiple Job Holding) } \\
\hline & \multicolumn{3}{|c|}{ Model 1} & \multicolumn{3}{|c|}{ Model 2} \\
\hline & $\begin{array}{c}\text { Full } \\
\text { Sample }\end{array}$ & $\begin{array}{c}\text { Sample with } \\
\text { Increased } \\
\text { Income } \\
\end{array}$ & $\begin{array}{c}\text { Sample with } \\
\text { Decreased } \\
\text { Income } \\
\end{array}$ & $\begin{array}{c}\text { Full } \\
\text { Sample }\end{array}$ & $\begin{array}{c}\text { Sample with } \\
\text { Increased } \\
\text { Income } \\
\end{array}$ & $\begin{array}{c}\text { Sample with } \\
\text { Decreased } \\
\text { Income } \\
\end{array}$ \\
\hline $\begin{array}{c}\text { Sector } \\
\text { (1=Agriculture) }\end{array}$ & $(0.009)^{* * *}$ & $(0.012)^{* * *}$ & $(0.022)^{* * *}$ & $(0.009)^{* * *}$ & $(0.010)^{* * *}$ & $(0.098)^{* * *}$ \\
\hline Dummy Main Job & -0.05689 & -0.06950 & -0.01528 & -0.05693 & -0.05135 & -0.04697 \\
\hline $\begin{array}{l}\text { Status } \\
\qquad(1=\text { Paid Worker) }\end{array}$ & $(0.011)^{* * *}$ & $(0.017)^{* * *}$ & $(0.023)$ & $(0.011)^{* * *}$ & $(0.014)^{* * *}$ & $(0.101)$ \\
\hline $\begin{array}{l}\text { Dummy Location } \\
\text { (1=Urban) }\end{array}$ & $\begin{array}{c}-0.02852 \\
(0.008)^{* * *}\end{array}$ & $\begin{array}{c}-0.03115 \\
(0.010)^{* * *}\end{array}$ & $\begin{array}{c}-0.21222 \\
(0.023) \\
\end{array}$ & $\begin{array}{r}-0.02881 \\
(0.008)^{* * *} \\
\end{array}$ & $\begin{array}{r}-0.02407 \\
(0.009)^{* * *} \\
\end{array}$ & $\begin{array}{c}-0.09451 \\
(0.095) \\
\end{array}$ \\
\hline $\mathrm{N}$ & 11,714 & 8,787 & 2,587 & 11,714 & 8,787 & 2,587 \\
\hline
\end{tabular}

Source: Author's computation using data from IFLS 2007 and 2014

${ }^{* * *} \mathrm{p}<0.01,{ }^{* *} \mathrm{p}<0.05,{ }^{*} \mathrm{p}<0.1$

The number in brackets () indicates the standard error

Based on the above table, using the full sample, those who have multiple jobs in 2007 have a higher probability to have multiple jobs in 2014. This indicates that multiple job holding takes place permanently. However, we do not find a significant impact of the change in the income from the main job on the probability of having multiple jobs in 2014. This is probably because there are workers who experienced an increase in their income while some others experienced a decrease in their income, which may result in insignificant parameter. We then split the sample for those who experienced an increase in their income and those who experience a decrease in their income. As the result, we have 8,787 observations from those with income increase and 2,587 observations from those with income decrease.

After splitting the sample, we found that the higher the percentage of income increase, the lower is the probability to have multiple jobs in 2014. For workers who experienced a decrease in income from their primary job, we found that the higher the income decrease, the higher is the probability to keep the multiple job in 2014, which implies a permanent multiple job holding. The interaction between (the absolute) income decrease and initial status of multiple job holding is positive and statistically significant. This implies that for workers who had multiple job in 2007, the higher the percentage decrease in their income from their primary job, the higher is the probability to remain as a multiple job holders in 2014, indicating permanent phenomenon.Those who have higher income (from the primary job) in 2007 is less likely to have multiple job in 2014 in five out of six specifications.

With regard to gender, we found that male workers have a higher probability to have multiple jobs in 2014. Based on workers' age, the probability of having multiple jobs in 2014 follows an inverted U-shaped curve, indicated by a positive parameter of variable age and negative parameter of variable age-squared. For education variables, we found interesting results. Specifically, workers with basic education have a lower probability to have multiple jobs in 2014, while those with university education have a higher probability to have multiple jobs. We argue that - other things being constant workers with higher education have a greater chance of obtaining a second job than those with lower educational background. The numbers of hours in the main job is negatively correlated with the probability of having multiple jobs. 
This is not surprising as the longer the workers spend in their primary job, the higher is the marginal utility of leisure which causes them to increase their reservation wage for the second job. The probability of agricultural workers to have multiple jobs is higher than those in non agricultural sector, and those who live in rural have a higher probability to have multiple jobs than those living in urban. These results are consistent with our descriptive statistics.

\subsection{Multinomial Logit Estimation Results of Multiple Job Holding Decision}

As a robustness check, we also conduct a Multinomial Logit estimation to analyze the probability of workers to stay or change their job holding decision. The estimation results in Table 12 suggest for those who were single job holders, one percent increase in the primary job income increases the probability to stay as single job holder in 2014. For those who were multiple job holders in 2007, a higher percentage income increase from the primary job, the lower is the probability to move to single job holding. We argue that although the workers in this category experienced an increase in their income, only a significant income increase enabled them to move from multiple job holders to single job holders. Given that workers with low income (from the primary job) are more likely to have multiple jobs, they will continue to have multiple jobs if their income increase failed to meet their needs.

To check our argument, we provide descriptive statistics on the primary job income in 2007 and its associated changes for each group in Table 13. The median of the primary job income for those who stayed as single job holders is higher than the median income of the other groups. They also had the greatest median of income increase. Table 13 also shows that the median primary job income of the multiple job holders in 2007 is the smallest among all groups. The multiple job holders in 2007 who became single job holders in 2014 had the second largest increase in their income from the primary job, while those who remain multiple job holders had the lowest (median) income increase. This indicates to support our claim that only a significant income increase that enables workers who were previously multiple job holders to become single job holders.

\section{CONCLUSION}

This study finds that the multiple job holding decision in 2014 is highly correlated with multiple job holding in 2007. The level of income from the primary job and its percentage changes play an important role in determining multiple job holding decision. We found that the higher the income from the primary job, the lower is the probability of a worker to have multiple jobs. We also found that the higher the percentage income increase from the primary job, the lower is the probability to become a multiple job holder. Those who were previously multiple job holders require a significant amount of income increase to become to single job holders. We showed that the median increase of income from the primary job for those who remain multiple job holders in 2007 and 2014 were lowest among other groups. This implies that although they experienced an increase of their income, their income from the primary job remain low (and most likely failed to meet their need). Thus, they will continue to have multiple jobs. We argue that this a plausible explanation of why we the number of multiple job holders is increasing over time despite the income is generally increasing. 
Table 12. Multinomial Logit Estimation Results of Multiple Job Holding Decision

\begin{tabular}{|c|c|c|c|c|}
\hline \multirow[b]{2}{*}{ Variable } & \multicolumn{4}{|c|}{ Multinomial Logit Model } \\
\hline & $\begin{array}{c}\text { Single-Single } \\
\text { Job Holder }\end{array}$ & $\begin{array}{c}\text { Single-Multiple } \\
\text { Job Holder }\end{array}$ & $\begin{array}{c}\text { Multiple-Single } \\
\text { Job Holder }\end{array}$ & $\begin{array}{c}\text { Multiple-Multiple } \\
\text { Job Holder }\end{array}$ \\
\hline \multirow[t]{2}{*}{ Income Main Job } & 0.00027 & -0.00012 & -0.00019 & 0.00014 \\
\hline & $(0.000)^{* * *}$ & $(0.000)$ & $(0.000)^{* * *}$ & $(0.000)$ \\
\hline \multirow[t]{2}{*}{ Ln(Income Main Job in 2007) } & 0.05479 & -0.00939 & -0.03496 & -0.01044 \\
\hline & $(0.005) * * *$ & $(0.005)^{*}$ & $(0.005)^{* * *}$ & $(0.002)^{* * *}$ \\
\hline \multirow{2}{*}{$\begin{array}{c}\text { Dummy Gender } \\
\text { (1=Male) }\end{array}$} & -0.16374 & 0.06106 & 0.04467 & 0.05800 \\
\hline & $(0.018) * * *$ & $(0.027)^{* *}$ & $(0.010)^{* * *}$ & $(0.009) * * *$ \\
\hline \multirow[t]{2}{*}{ Age } & -0.0226 & 0.00372 & 0.01089 & 0.00799 \\
\hline & $(0.004) * * *$ & $(0.003)$ & $(0.004)^{* * *}$ & $(0.002)^{* * *}$ \\
\hline \multirow[t]{2}{*}{ Age Squared } & 0.00022 & -0.00006 & -0.00008 & -0.00008 \\
\hline & $(0.000) * * *$ & $(0.000)$ & $(0.000)^{* *}$ & $(0.000) * * *$ \\
\hline \multirow{2}{*}{$\begin{array}{l}\text { Dummy Basic Education } \\
\quad \text { (1=Elementary) }\end{array}$} & 0.02225 & -0.02364 & -0.00319 & 0.00458 \\
\hline & $(0.013)^{*}$ & $(0.012)^{* *}$ & $(0.008)$ & $(0.003)$ \\
\hline \multirow{2}{*}{$\begin{array}{l}\text { Dummy High Education } \\
\text { (1=University) }\end{array}$} & -0.07923 & 0.01253 & 0.04588 & 0.02081 \\
\hline & $(0.013)^{* * *}$ & $(0.009)$ & $(0.011)^{* * *}$ & $(0.005) * * *$ \\
\hline \multirow{2}{*}{$\begin{array}{l}\text { Dummy Marital Status } \\
\text { (1=Married) }\end{array}$} & -0.04351 & -0.00621 & 0.02542 & 0.02430 \\
\hline & $(0.014) * * *$ & $(0.008)^{* *}$ & $(0.010)^{* *}$ & $(0.004)^{* * *}$ \\
\hline Number of Houshold & -0.00239 & -0.00004 & 0.00157 & 0.00086 \\
\hline MembersWorking & $(0.002)$ & $(0.001)$ & $(0.002)$ & $(0.001)$ \\
\hline Total other Houshold & 0.00004 & -0.00004 & 0.00002 & 0.00001 \\
\hline Members Income & $(0.000)^{* *}$ & $(0.000)^{* *}$ & $(0.000)^{*}$ & $(0.000)^{*}$ \\
\hline \multirow{2}{*}{$\begin{array}{l}\text { Hours Worked Main Job } \\
\text { (month) }\end{array}$} & 0.00038 & -0.00023 & 0.00001 & -0.00016 \\
\hline & $(0.000)^{* * *}$ & $(0.000)^{* *}$ & $(0.000)$ & $(0.000)^{* * *}$ \\
\hline \multirow{2}{*}{$\begin{array}{l}\text { Dummy Main Job Sector } \\
\quad \text { (1=Agriculture) }\end{array}$} & -0.07313 & 0.02371 & 0.02803 & 0.02139 \\
\hline & $(0.012)^{* * *}$ & $(0.012)^{* *}$ & $(0.009)^{* * *}$ & $(0.004)^{* * *}$ \\
\hline \multirow{2}{*}{$\begin{array}{l}\text { Dummy Main Job Status } \\
\qquad(1=\text { Paid Worker })\end{array}$} & 0.08107 & -0.03772 & -0.02354 & -0.01981 \\
\hline & $(0.014)^{* * *}$ & $(0.017)^{* *}$ & $(0.009)^{* * *}$ & $(0.005) * * *$ \\
\hline \multirow{2}{*}{$\begin{array}{l}\text { Dummy Location } \\
\text { (1=Urban) }\end{array}$} & 0.10759 & -0.00790 & -0.06904 & -0.03065 \\
\hline & $(0.012)^{* * *}$ & $(0.007)$ & $(0.012)^{* * *}$ & $(0.006) * * *$ \\
\hline
\end{tabular}

Source: Author's computation using data from IFLS 2007 and 2014

${ }^{* * *} \mathrm{p}<0.01,{ }^{* *} \mathrm{p}<0.05,{ }^{*} \mathrm{p}<0.1$

The number in brackets () indicates the standard error

Table 13. Descriptive Statistics of Income from the Main Job by Workers Categories

\begin{tabular}{|c|c|c|c|c|}
\hline & $\begin{array}{c}\text { Single- } \\
\text { Single Job } \\
\text { Holder } \\
\end{array}$ & $\begin{array}{c}\text { Single- } \\
\text { Multiple Job } \\
\text { Holder }\end{array}$ & $\begin{array}{c}\text { Multiple- } \\
\text { Single Job } \\
\text { Holder } \\
\end{array}$ & $\begin{array}{c}\text { Multiple- } \\
\text { Multiple Job } \\
\text { Holder } \\
\end{array}$ \\
\hline \multicolumn{5}{|c|}{ Mean } \\
\hline Main Job Income in 2007 & 753,030 & $700,988.3$ & $525,073.2$ & $544,379.3$ \\
\hline Main Job Income in 2014 & $3,024,414$ & $2,618,522$ & $2,295,690$ & $2,075,997$ \\
\hline Main Job Income Increase in 2007-2014 & $2,271,384$ & $1,917,534$ & $1,770,616$ & $1,531,617$ \\
\hline \multicolumn{5}{|c|}{ Median } \\
\hline Main Job Income in 2007 & 575,000 & 500,000 & 300,000 & 300.000 \\
\hline Main Job Income in 2014 & $1,710,000$ & $1,500,000$ & $1,500,000$ & $1,350,000$ \\
\hline Main Job Income Increase in 2007-2014 & $1,097,000$ & 900,000 & $1,000,000$ & 850,000 \\
\hline $\mathrm{N}$ & 6,327 & 1,754 & 1,416 & 1,151 \\
\hline
\end{tabular}

Source: Author's computation using data from IFLS 2007 and 2014 


\section{REFERENCES}

Alam, S., Biswas, K., \& Hassan, K. (2009). A test of association between working hour and work family conflict: A glimpse on Dhaka's female white collar professionals. International Journal of Business and Management, 4(5), 27-35.

Altonji, J. G., \& Paxson, C. H. (1988). Labor supply preferences, hours constraints, and hours-wage trade-offs. Journal of Labor Economics, 6(2), 254-276.

Averett, S. L. (2001). Moonlighting: Multiple motives and gender differences. Applied Economics, 33(11), 1391-1410.

Bell, D., Hart, R. A., \& Wright, R. E. (1997). Multiple job holding as a 'hedge' against unemployment. Center for Economic Policy Research Discussion Papers, 1626.

Böheim, R., and Taylor, M. P. (2004). Actual and preferred working hours. British Journal of Industrial Relations, 42(1), 149166.

Casacuberta, C., and Gandelman, N. (2012). Multiple job holding: The artist's labour supply approach. Applied Economics, 44(3), 323-337.

Danzer, A. (2011). Labor supply and consumption smoothing when income shocks are non-insurable. Institute for the Study of Labor Discussion Paper, 5499.

Dickey, H., Watson, V., \& Zangelidis, A. (2009). What triggers multiple job holding? An experimental investigation. (MPRA Paper). University Library of Munich

Friesen, J. (2001). Overtime pay regulationsand weekly hours of work in Canada. Labour Economics, 8(6), 691-720.

Hodge, I., Dunn, J., Monk, S., \& Fitzgerald, M., (2002). Barriers to participation in residual rural labour markets. Work, Employment and Society, 16(3), 457-476.

ILO. 2004. Conditions of work and employment programme. Information Sheet, WT-19.

Kimmel, J., \& Smith Conway, K. (2001). Who moonlights and why? Evidence from the SIPP. Industrial Relations: A Journal of Economy and Society, 40(1), 89-120.

Krishnan, P. (1990). The economics of moonlighting: a double self-selection model. Review of Economics and Statistics,
72(2), 361-367.

Lundborg, P. (1995). Job amenity and the incidence of double work. Journal of Economic Behavior \& Organization, 26(2), 273-287.

Martinez, A., Western, M., Haynes, M., Tomaszewski, W., \& Macarayan, E. (2014). Multiple job holding and income mobility in Indonesia. Research in Social Stratification and Mobility, 37, 91-104.

Mather, M., \& Scopilliti, M. (2004). "Multiple job holding rates higher in rural America". Population Reference Bureau, September. Retrieved from http://www. prb.org/rfdcenter/MultipleJobholdingRates. htm.

Monk, S., and Hodge, I. (1995). Labour markets and employment opportunities in rural Britain. Sociologia Ruralis, 35(2), 153-172.

Panos, G., Pouliakas, K., \& Zangelidis, A. (2014). Multiple job holding, Skill Diversification, and Mobility. Industrial Relations, 53(2), 223-272.

Paxson, C. H., \& Sicherman, N. (1996). The dynamics of dual job holding and job mobility. Journal of Labor Economics, 14(3).

Renna, F., \& Oaxaca, R. (2006). The economics of dual job holding: A job portfolio model of labor supply. Institute for the Study of Labor Discussion Paper, 1915.

Robinson, H., \& Wadsworth, J. (2007). Impact of the minimum wage on the incidence of second job holding in Britain. Scottish Journal of Political Economy, 54(4), 553574.

Shishko, R., \& Rostker, B. (1976). The Economics of multiple job holding. American Economic Review, 66(3), 298-308.

Smith Conway, K., \& Kimmel, J. (1998). Male labor supply estimates and the decision to moonlight. Labour Economics, 5(2), 135166.

Strauss, J., Witoelar, F., \& Sikoki, B. (2016). The fifth wave of the Indonesia family life survey: Overview and field report.

Taylor, C. N., and Little, H. M. (1995). Means of survival?: A study of off-farm employment in New Zealand. Taylor Baines and Associates. 
Wu, Z., Baimbridge, M., \& Zhu, Y. (2009).

Multiple job holding in the united kingdom:

evidence from the british household panel

survey. Applied Economics, 41(21), 2751-

2766.

Notice: The Journal of Indonesian Economy and Business and its Board of Editors are not responsible for any errors or flaws found in this article. The authors take full responsibility for their work. 